\title{
Quality of Preclinical and Clinical Root Canal Fillings performed by Undergraduate Students on Single-rooted Teeth
}

\author{
Manoel Brito-Júnior, Carla Cristina Camilo, Daniela Araújo Veloso Popoff, Rajiv Saini, André Luis Faria-e-Silva
}

\begin{abstract}
This study evaluated the radiographic technical quality of preclinical and clinical root canal fillings (RCF) performed by undergraduate students on single-rooted teeth. Two independent calibrated endodontic specialists evaluated 94 preclinical radiographs (group 1) and 96 clinical radiographs (group 2). The apical length of each RCF was categorized as acceptable (0-2.0 mm short of the radiographic apex), underfilled (2.0 $\mathrm{mm}$ or more short of the radiographic apex) and overfilled (extruded beyond the radiographic apex). Inadequate or adequate homogeneity were also evaluated based on the presence of voids and the uniform density of the R CF. Cohen's kappa and Chi-square tests $(p<0.05)$ were used for statistical analysis. The interexa miner agreement level was almost perfect $(>0.80)$. Approximately $80 \%$ of RCF had acceptable length in both groups, with no significant differences among them $(p>0.05)$. The rate of adequate homogeneity was higher in Group 2 when compared with group 1 ( $p<0.05)$. Overall, the quality of RCF was satisfactory with better homogeneous seal at the clinical level.
\end{abstract}

Keywords: Dental students, R oot canal filling, Endodontics.

How to citethis article: B rito-J únior $M, C$ amilo CC, P opoff DAV, Saini R, F aria-e-Silva AL. Quality of $P$ reclinical and C linical R oot Canal Fillings performed by Undergraduate Students on Singlerooted Teeth. Int J Experiment Dent Sci 2012;1(2):71-74.

\section{Source of support $\mathrm{Nil}$}

Conflict of interest: None declared

\section{INTRODUCTION}

Teaching in endodontics begins with preclinical activities in which fundamental technical concepts are established. With simulation clinics and training, preclinical laboratories improve the student's performance regarding cleaning, shaping and root canal fillings (RCF) ${ }^{1,2}$ The sedimentation of knowledge takes place through the clinical application of the acquired instructions and complements the teachinglearning process. ${ }^{3}$

A nother educational objective includes the evaluation of the endodontic therapy outcome. This approach favors a critical overview concerning the procedures performed by students and reinforces the concept that assessment of the therapeutic results should be an integral part of the treatment plan. ${ }^{4,5}$ In this regard, the RCF quality is essential to estimate the endodontic prognosis, once the major objective of RCF is to prevent reinfection and allow healing of the periapical tissues. ${ }^{1,3}$
The radiographical evaluation based on homogeneity and apical length of RCF is the main method that is used to determine the technical standard of endodontic therapy. A $n$ adequate RCF is characterized by a homogeneous filling (e.g. adequate density and tapering) placed within 0.0 to $2 \mathrm{~mm}$ of the radiographical root apex. ${ }^{6}$ These criteria have been used worldwide to evaluate the technical quality of RCF performed in undergraduate dental clinics. ${ }^{7-10}$ However, comparative data on RCF from preclinical and clinical activities are scarce.

Thus, this radiographic study evaluated the quality of RCF performed by undergraduate students on single-rooted teeth in preclinical and clinical practices. The null hypothesis tested was that there are no significant differences of RCF quality between these two stages of endodontic teaching.

\section{MATERIALS AND METHODS}

\section{Sample}

A random sample of 200 final radiographs of endodontically treated teeth (extracted teeth) from a laboratory and of patients who had received endodontic treatment was examined. The RCF were performed in single-rooted teeth (incisors, canines or premolars) in the period from 2005 to 2006 by 3rd year undergraduate students at D ental School of State U niversity of M ontes Claros, M inas Gerais, B razil.

\section{Endodontic Procedures}

In the laboratory, the teeth were fixed in a vise to facilitate the handling during the technical procedures. A II teeth were treated using the same standard root canal preparation and filling techniques for both preclinical and clinical stages. Thus, coronal access was performed with a \#1557 tapered carbide bur (SS White Dental products, Rio de Janeiro, B razil) at high speed, followed by a compensatory wear with Endo-Z bur (Dentsply/M aillefer, B allaigues, V allorbe, Switzerland). $M$ anual root instrumentation was performed with K -files and \#2-4 Gates Glidden Drills (Dentsply/ M aillefer) using a crown-down technique. In all root canals, the apical patency was maintained with \#10/15 K -files. The apical limit of enlargement/shaping was established at approximately $1 \mathrm{~mm}$ short of the patency length. The root 
canals were irrigated with a $2.5 \%$ sodium hypochlorite solution (B iodinâmica Produtos Q uímicos L tda, I biporã, PR, $B$ razil) between each instrument, followed by smear layer removal with $14.3 \%$ EDTA solution (pH 7.4; OdahcamHerpo Produtos Dentários, Petrópolis, RJ, B razil) for 3 minutes and a new irrigation with sodium hypochlorite.

A fter drying with paper points, the root canals were filled with nonstandardized gutta-percha cones ( $O$ dous, B elo Horizonte, M G, Brazil) and a zinc oxide eugenol-based sealer (Endofill, D entsply, Petrópolis, RJ, B razil) using the lateral condensation technique. First, the initial diameter $\left(D_{0}\right)$ of the master gutta-percha cone was standardized with a calibrating ruler (A ngelus, L ondrina, PR, B razil) and its point was regularized with a blade \#15. The master cone was tested in the root canal until it precisely reached the working length. A fterwards the sealer was manipulated according to the manufacturer's instructions and inserted in the root canal using a master apical file. The master cone coated with sealer was inserted into the canal up to the working length, followed by active lateral condensation. Thus, the space created by finger spreaders (Dentsply/ $M$ aillefer) was progressively filled with an accessory cone coated with sealer and inserted into the canal until resistance was felt. Having concluded the filling, the excess material was removed, and the crown openings were restored with either zinc oxide eugenol cement (IRM, Caulk/D entsply, Rio de J aneiro, RJ, B razil) or glass ionomer cement (V idrion C, SS White), following by orthoradial radiographic evaluation.

The periapical radiographs were taken on Ekta-Speed film (Eastman Kodak, New Y ork, NY, USA) using the bisecting angle technique in a dental $X$-ray unit with 70 $\mathrm{K} v \mathrm{p}$ and $10 \mathrm{M} \mathrm{a}$ (Dabi A tlante, Ribeirão Preto, SP, B razil). The visual method was used to process the radiographs, followed by rinsing in water for 10 minutes, drying and filing.

\section{Groups and Evaluation Criteria}

The sample was divided into group 1 (100 radiographs of preclinical treatments, numbered from 1 to 100 ) and group 2 (100 radiographs of clinical treatments, numbered from 101 to 200).

Using an $\mathrm{X}$-ray viewer at $2 \mathrm{x}$ magnification, two independent calibrated endodontic specialists assessed the apical length and homogeneity of each RCF. The apical length was categorized as acceptable $(0-2.0 \mathrm{~mm}$ short of the radiographic apex), underfilled $(2.0 \mathrm{~mm}$ or more short of the radiographic apex) and overfilled (extruded beyond the radiographic apex). Inadequate or adequate homogeneity, based on the presence of voids and the uniform density of the filling respectively, were also evaluated. Such criteria were based on previous studies. ${ }^{8,10}$ The exclusion criteria were poorly processed and/or stored radiographs that did not allow appropriate visualization of the analyzed items.

\section{Data Analysis}

The data obtained were tabulated, transformed into percentages and submitted to the statistical Chi-squared test $(p<0.05)$. In addition, the Kappa test was used to verify the agreement level between the two examiners.

\section{RESULTS}

Six radiographs were excluded from group 1, and four from group 2 due to density and processing errors. The interexaminer Kappa index was of 0.86 , representing an almost perfect level of agreement. Thus, a total of 190 periapical radiographs were analyzed.

Table 1 shows that approximately $80 \%$ of the RCF s had acceptable length in both groups. Overfillings were present in $3.2 \%$ in group 1 and $8.3 \%$ in group 2 . Regarding the homogeneity, 77.6 and $90.6 \%$ were adequate in groups 1 and 2 respectively (Table 2 ). When comparing the two groups, a statistically significant difference could be observed in relation to the homogeneity and overfillings ( $p<0.05$ ), with the former group presenting a better performance in clinical practice and the latter in the laboratory.

\section{DISCUSSION}

Although buccolingual radiographs are essentially a twodimensional representation of a three-dimensional object, the radiographic analysis provides several criteria that enable the quality of the RCFs to be judged. ${ }^{11,12}$ In the present study, the RCF presented different behavior in preclinical and clinical activities for radiographic parameters evaluated. Thus, the null hypothesis was rejected.

A $n$ inadequate RCF presents gross deficiencies and generally represents a graphic record of the insufficient root canal preparation. Complete disinfection of the root canals is not achieved in these situations. ${ }^{13,14}$ The present study showed that approximately 77 and $90 \%$ of RCF presented adequate density in the laboratorial and clinical phases respectively. These findings demonstrate satisfactory technical performance of the undergraduates, corroborating previous results reported at other dental schools. ${ }^{4,5}$ Nevertheless, using criteria similar those adopted herein, several studies ${ }^{6,10}$ have shown a poor quality of endodontic fillings performed by undergraduate dental students. 
Quality of Preclinical and C linical R oot Canal F illings performed by Undergraduate Students on Single-rooted Teeth

Table 1: The apical length of preclinical and clinical root canal fillings

Group Apical length

\begin{tabular}{|c|c|c|c|c|c|c|c|c|}
\hline & \multicolumn{2}{|c|}{ Acceptable } & \multicolumn{2}{|c|}{ Underfilled } & \multicolumn{2}{|c|}{ Overfilled } & \multicolumn{2}{|c|}{ Total } \\
\hline & $\mathrm{N}$ & $\%$ & N & $\%$ & $\mathrm{~N}$ & $\%$ & N & $\%$ \\
\hline $\begin{array}{l}\text { 1. Preclinical } \\
\text { 2. Clinical }\end{array}$ & $\begin{array}{l}76 \\
77\end{array}$ & $\begin{array}{l}80.9^{a} \\
80.2^{a}\end{array}$ & $\begin{array}{l}15 \\
11\end{array}$ & $\begin{array}{l}16.0^{\mathrm{a}} \\
11.5^{\mathrm{a}}\end{array}$ & $\begin{array}{l}3 \\
8\end{array}$ & $\begin{array}{l}3.2^{\mathrm{a}} \\
8.3^{\mathrm{b}}\end{array}$ & $\begin{array}{l}94 \\
96\end{array}$ & $\begin{array}{l}100 \\
100\end{array}$ \\
\hline
\end{tabular}

a,b Statistical difference between groups for each parameter $(p<0.05)$

\begin{tabular}{|c|c|c|c|c|c|c|}
\hline \multirow[t]{3}{*}{ Group } & \multicolumn{6}{|c|}{ Homogeneity } \\
\hline & \multicolumn{2}{|c|}{ Adequate } & \multicolumn{2}{|c|}{ Inadequate } & \multicolumn{2}{|c|}{ Total } \\
\hline & $\mathrm{N}$ & $\%$ & $\mathrm{~N}$ & $\%$ & $\mathrm{~N}$ & $\%$ \\
\hline $\begin{array}{l}\text { 1. Preclinical } \\
\text { 2. Clinical }\end{array}$ & $\begin{array}{l}73 \\
87\end{array}$ & $\begin{array}{l}77.7^{\mathrm{a}} \\
90.6^{\mathrm{b}}\end{array}$ & $\begin{array}{c}21 \\
9\end{array}$ & $\begin{array}{l}22.3^{a} \\
9.4^{a}\end{array}$ & $\begin{array}{l}94 \\
96\end{array}$ & $\begin{array}{l}100 \\
100\end{array}$ \\
\hline
\end{tabular}

a,b Statistical difference between groups for each parameter $(p<0.05)$

In this study, the apical length of the root fillings was classified as acceptable in approximately $80 \%$ of the cases at both preclinical and clinical stages. This rate demonstrates that undergraduates have correctly assimilated this important requirement of the endodontic technique equivalent to performance of graduate dental students. ${ }^{15}$ These results may be due to the fact that dental students take several radiographs during endodontic therapy to determine correct working lengths. In addition, it should be pointed out that the undergraduate students of the present study were closely supervised by endodontic specialists on the university teaching staff. The ratio of endodontic staff to students was 1: 6. Considering similar aspects, another study ${ }^{16}$ conducted at a dental school in Ireland reported a satisfactory rate (70\%) of root fillings clinically placed on single-rooted teeth.

In the present investigation, the rate of overfillings in clinical practice was significantly higher than in the laboratory stage. This is an undesirable occurrence in contemporary endodontics due to the possibility of negatively affecting the treatment outcome. ${ }^{17}$ However, a clinical prospective study ${ }^{13}$ demonstrated that a small extrusion of filling material did not have a negative impact on the endodontic therapy success. Thus, the cases evaluated in the present study can be assured of a positive prognosis, because of the small amount of overfillings, predominantly made up of cements.

Considering the clinical results of this study, it can be assumed that the quality rating of the endodontic fillings was high, which is in agreement with previous investigations. ${ }^{4,5,16}$ However, there are discrepancies as regards the results found by Eckerbom, ${ }^{11}$ whose rates of inadequate fillings ranged from 54 to $62 \%$. This discrepancy can possibly be explained by the fact that the above-mentioned studies evaluated the treatment performed by students under supervised conditions, whereas the others represent general practice. Furthermore, those investigations ${ }^{11}$ evaluated all dental groups, in contrast with the present study, which analyzed RCF s on single-rooted teeth.

\section{REFERENCES}

1. Ingle J I, B akland LK, B aumgartner J (Eds). Ingle's endodontics (6th ed). Hamilton, Ontario: BC Decker, Inc 2008:1400-25.

2. Ünal GÇ, M aden M, Orhan EO, Sarıtekin E, Teke A. R oot canal shaping using rotary nickel-titanium files in preclinical dental education in Turkey. J Dent Educ 2012;76:509-13.

3. Torabinejad M, W al ton R. Endodontics: Principles and practice (4th ed). St Louis: Saunders/Elsevier 2009:58-63.

4. B enenati $\mathrm{FW}, \mathrm{K}$ hajotia SS. A radiographic recall evaluation of 894 endodontic cases treated in a dental school setting. J Endod 2002;28:391-95.

5. De Quadros I, Gomes BP, Zaia AA, Ferraz CC, Souza-Filho $F$ J. Evaluation of endodontic treatments performed by students in a Brazilian dental school. J Dent Educ 2005;69:1161-70.

6. Barrieshi-Nusair KM, Al-Omari M A, Al-Hiyasat AS. Radiographic technical quality of root canal treatment performed by dental students at the dental teaching center in J ordan. J D ent 2004;32:301-07.

7. K habbaz M G, Protogerou E, Douka E. Radiographic quality of root fillings performed by undergraduate students. Int Endod J 2010;43:499-508.

8. Unal GC, K ececi AD, K aya BU, Tac A G. Quality of root canal fillings performed by undergraduate dental students. Eur J D ent 2011;5:324-30.

9. Balto H, AI K halifah Sh, AI M ugairin S, A I D eeb M, A I-M adi $E$. Technical quality of root fillings performed by undergraduate students in Saudi A rabia. Int Endod J 2010;43:292-300.

10. Elsayed RO, A bu-Bakr NH, I brahim Y E. Quality of root canal treatment performed by undergraduate dental students at the University of K hartoum, Sudan. A ust Endod J 2011;37:56-60. 
11. Eckerbom M. Prevalence and technical standard of endodontic treatment in a Swedish population. A Iongitudinal study. Swed Dent J Suppl 1993;93:1-45.

12. Eckerbom $M, M$ agnusson $T$. Evaluation of technical quality of endodontic treatment-reliability of intraoral radiographs. Endod Dent Traumatol 1997;13:259-64.

13. Sjögren U, Figdor D, Persson S, Sundqvist G. Influence of infection at the time of root filling on the outcome of endodontic treatment of teeth with apical periodontitis. Int Endod J 1997;30:297-306.

14. Sundqvist G, Figdor D, Persson S, Sjögren U. M icrobiologic analysis of teeth with failed endodontic treatment and the outcome of conservative retreatment. Oral Surg Oral M ed Oral Pathol Oral Radiol Endod 1998;85:86-93.

15. Santos SM, Soares J A, C ésar CA, B rito-J únior M, M oreira A N, $M$ agalhães CS. Radiographic quality of root canal fillings performed in a postgraduate program in endodontics. B raz D ent J 2010;21:315-21.

16. Lynch CD, B urke FM . Q uality of root canal fillings performed by undergraduate dental students on single-rooted teeth. Eur J Dent E duc 2006;10:67-72.

17. Sjögren $U, H$ ägglund $B$, Sundqvist $G, W$ ing K . Factors affecting the long-term results of endodontic treatment. J Endod 1990 16:490-504.

\section{ABOUT THE AUTHORS}

\section{Manoel Brito-Júnior (Corresponding Author)}

Professor, D epartment of Dentistry, State U niversity of M ontes Claros M inas Gerais, B razil, e-mail: manoelbritojr@gmail.com

\section{Carla Cristina Camilo}

Professor, D epartment of D entistry, State U niversity of M ontes Claros M inas Gerais, B razil

\section{Daniela Araújo Veloso Popoff}

Professor, D epartment of D entistry, State U niversity of M ontes Claros M inas Gerais, B razil

\section{Rajiv Saini}

A ssistant Professor, D epartment of Periodontology, Pravara Institute of M edical Sciences, A hmednagar, M aharashtra, India

\section{André Luis Faria-e-Silva}

Professor, Department of Dentistry, Federal University of Sergipe Sergipe, Brazil 